\title{
An ecosystem level experiment on nutrient limitation in temperate coastal marine environments
}

\author{
Candace Oviatt ${ }^{1}$, Peter Doering ${ }^{1}$, Barbara Nowicki ${ }^{1}$, Laura Reed ${ }^{1}$, Jonathan Cole ${ }^{2}$, \\ Jeffrey Frithsen ${ }^{3}$
} ${ }^{1}$ Graduate School of Oceanography, University of Rhode Island, Narragansett Bay Campus, Narragansett,
Rhode Island 02882, USA

${ }^{2}$ Institute of Ecosystem Studies, Mary Flagler Cary Arboretum, Box AB, Millibrook, New York 12545, USA

${ }^{3}$ Versar, Inc., 9200 Rumsey Road, Columbia, Maryland 21045, USA

\begin{abstract}
Which nutrients limit primary production in coastal marine environments? Using large (13000 l) mesocosms with sediments we explored nutrient limitation in Narragansett Bay, Rhode Island, USA, over a $9 \mathrm{wk}$ period. Separate and combined additions of phosphorus and nitrogen were made to the enclosures. Phytoplankton biomass, daytime whole system oxygen production and nighttime whole system respiration showed an approximately 5 -fold increase in nitrogen and nitrogen + phosphorus treatments, whereas phosphorus treatments had somewhat lower phytoplankton biomass and metabolism than controls. In these whole system experiments nitrogen was the nutrient most limiting to primary production.
\end{abstract}

KEY WORDS: Nutrient limitation · Primary production · Enclosed marine ecosystem

\section{INTRODUCTION}

In many aquatic environments, phytoplankton growth may be controlled by the supply of limiting nutrients, usually nitrogen or phosphorus (Howarth 1988). According to the literature, phytoplankton in freshwaters tends to be phosphorus limited, while phytoplankton in marine waters tends to be nitrogen limited. Whole lake experiments in Ontario, Canada, provided a clear demonstration that phosphorus was the nutrient causing eutrophication problems in these freshwater systems (Schindler 1974). That is, additions of phosphorus (with an additional small amount of nitrogen) resulted in massive algal blooms. In marine waters, assay experiments usually indicate nitrogen limitation. The evidence, however, that marine systems are in fact nitrogen limited is not nearly as strong as the evidence that freshwaters tend to be phosphorus limited. Hecky \& Kilham (1988) point out that while phosphorus limitation in freshwater is supported by evidence at several hierarchical levels, such is not the case for marine studies. Thus, while freshwater studies have included small-scale nutrient bioassays, meso- cosms, cross-system comparisons and whole-lake fertilizations, marine studies have included few whole-system fertilizations and few mesocosm studies (Schindler 1974, D'Elia et al. 1986, Caraco et al. 1987, Hecky \& Kilham 1988). In this paper we report the results of nitrogen and phosphorus enrichments of large $(13000$ 1) marine enclosures which include sediments.

In the marine environment the evaluations from bottle incubations and stoichiometry apparently contradict, fueling a continuing debate on nutrient limitation. The many flask experiments and observations of nutrient ratios would indicate nitrc , n limitation. The first and most often cited of these studies occurred in the waters of Long Island, New York, USA (Ryther \& Dunstan 1971). In Moriches Bay eutrophication problems were associated with duck farm effluents. While phosphorus concentration behaved semi-conservatively and followed a dilution gradient, nitrogen disappeared unconservatively, except in the tributaries that were in direct receipt of the duck farm effluent, resulting in the tentative conclusion that the phytoplankton were nitrogen limited (Ryther \& Dunstan 1971). Concurrent 
flask bioassays with nutrient additions generally showed no growth increase with phosphorus addition and large growth increases with ammonia additions. Subsequent examinations of nitrogen and phosphorus concentrations along the eastern seaboard and New York bight showed that where there were sources of nutrients, inorganic nitrogen rapidly dropped to oceanic levels, whereas phosphorus concentrations remained high (Ryther \& Dunstan 1971). Additional flask experiments repeated the previous results, with heavy growths of Skeletonema occurring in samples enriched with ammonia. These approaches have been criticized on the basis of not incorporating essential components of the natural ecosystem, introducing artifacts such as isolation from atmospheric gases and from sediments, which was a problem in freshwater flask studies, and on the basis of nutrient concentration ratios that fail to indicate nutrient flux rates or particulate matter composition (Hecky \& Kilham 1988, Smith 1991). The short time scale of incubations may prevent blooms of nitrogen-fixing bacteria (Vitousek \& Howarth 1991). Smith (1991), who describes a stoichiometric approach, fears that incubation assays including microcosm experiments decouple controlling processes and thus 'fail to describe the summed functions of the system'. For many shallow tropical systems and for the ocean as a whole, Smith $(1984,1991)$ calculates a phosphorus deficit based on system inputs and invokes nitrogen fixation to make up localized deficits to conclude that ultimately phosphorus is the limiting nutrient.

The complexity of processes potentially contributing to nutrient limitation makes the study of any single process unsatisfactory. With this in mind we have tried to mimic the whole lake studies for the coastal marine environment, incorporating all the appropriate ecosystem components and processes. In this paper we describe an experiment in enclosed marine ecosystems with a water column overlying a field-collected benthic community. Separate and combined additions of phosphorus and nitrogen at loading ratios similar to those used by Schindler (1974) in whole lake experiments were made to the experimental enclosures and changes in apparent daytime system production, nighttime respiration and $24 \mathrm{~h}$ net system production were measured and compared to control treatments.

\section{METHODS}

Enclosure description. The experimental systems simulated shallow, well-mixed, coastal ecosystems typical of the northeastern USA. The fiberglass wall of the interior of the enclosures was painted with a white epoxy paint to enhance penetration of sunlight through the water column. They contained seawater $\left(13.1 \mathrm{~m}^{3}\right)$ pumped from a depth of $2 \mathrm{~m}$ at the Graduate School of Oceanography dock using diaphram pumps. These pumps minimized mechanical stress on plankton. The systems contained an intact benthic community $\left(2.5 \mathrm{~m}^{2}\right)$ taken from mid Narragansett Bay. Sediments were collected during May 1988 using a $0.25 \mathrm{~m}^{2}$ USNEL spade box corer which minimized sediment disturbance and preserved most of the vertical structure to $36 \mathrm{~cm}$ of the sediment.

Light, temperature, turbulence and water turnover were considered important factors in the design of the enclosures. A water column depth of $5 \mathrm{~m}$ was chosen so that sediments would be below the $1 \%$ isolume most of the year. Glass heat exchangers connected to a cooling system maintained water temperature within $2{ }^{\circ} \mathrm{C}$ of ambient Narragansett Bay temperature. Turbulence was provided by a vertical plunger which rotated in an elliptical orbit at $5 \mathrm{rpm}$ for $2 \mathrm{~h}$ of every $6 \mathrm{~h}$. These cycles approximated tidal mixing in the bay and maintained suspended loads similar to those in the bay at 3 to $5 \mathrm{mg} \mathrm{l}^{-1}$. In most experiments seawater in the experimental systems has a turnover of about $1 \mathrm{mo}$. However, this experiment was conducted in batch mode to provide slow-growing nitrogen fixers time to increase their population size. Thus small amounts of seawater were added only to make up for sampling and evaporation losses.

Wall fouling in the system was minimized by using a wall cleaner having pneumatically driven rotating brushes. Walls were brushed twice weekly during the summer leaving a $1 \mathrm{~m}^{2}$ patch for nitrogen fixation studies. The small amounts of materials routinely brushed from the walls usually were fine enough to remain suspended for 1 or more mixing cycles before sinking to the bottom. The $1 \mathrm{~m}^{2}$ patches which were not cleaned grew luxuriant algal communities by the fall period, particularly in nitrogen treatments.

Experimental design. The experiment was designed with 4 treatments, each with 2 replicates (Table 1). The first batch addition of nutrients was added June 8, 1988, and intensive sampling was conducted to October 10,1988, similar to the experiment conducted in Lake 226 (Schindler 1974; Table 1). Methods are detailed in Lambert \& Oviatt (1986) and described here briefly.

Nutrients: Total nitrogen and phosphorus and total dissolved nitrogen and phosphorus were determined weekly using an adaptation of Valderrama (1981). Water samples were digested using persulphate oxidation and then analyzed for nitrate and phosphate concentrations using a Technicon Autoanalyzer. A precombusted Whatman GF/F, $1.2 \mu \mathrm{m}$, glass fiber filter was used to define the dissolved fraction in these analyses. The analytical precision $( \pm 1 \mathrm{SD})$ for total 
Table 1. Experimental outline compared to Lake 226 studies by Schindler (1974)

\begin{tabular}{|c|c|c|}
\hline & $\begin{array}{l}\text { Enclosures } \\
\text { ( } 2 \text { replicates) }\end{array}$ & $\begin{array}{l}\text { Lake } 226 \\
\text { (divided) }\end{array}$ \\
\hline \multirow[t]{4}{*}{ Treatments } & Control (no nutrients) & \\
\hline & $\begin{array}{l}\text { Phosphorus: } 47 \mathrm{mM} \mathrm{P} \mathrm{m}^{-2} \\
\text { or } 9.5 \mathrm{mM} \mathrm{P} \mathrm{m}^{-3}\end{array}$ & $9.6 \mathrm{mM} \mathrm{P} \mathrm{m}^{-3} \cdot \cdot$ \\
\hline & $\begin{array}{l}\text { Nitrogen: } 608 \mathrm{mM} \mathrm{N} \mathrm{m}^{-2} \\
\quad \text { or } 122 \mathrm{mM} \mathrm{N}^{-3}\end{array}$ & $113 \mathrm{mM} \mathrm{N} \mathrm{m}^{-3} \cdots$ \\
\hline & $\begin{array}{l}\text { Nitrogen + phosphorus: } \\
608 \mathrm{mM} \mathrm{N} \mathrm{m}^{-2} \text { and } \\
47 \mathrm{mM} \mathrm{P} \mathrm{m}^{-2}\end{array}$ & \\
\hline Nutrient forms & $\mathrm{NH}_{4}, \mathrm{PO}_{4}$ & $\mathrm{NO}_{3}, \mathrm{PO}_{4}$ \\
\hline Experimental duration & $16 \mathrm{wk}$ & $20 w k$ \\
\hline \multicolumn{3}{|c|}{$\cdot$ Physically divided in two } \\
\hline
\end{tabular}

production and nighttime respiration (Oviatt et al. 1986). Replicate oxygen samples were analyzed by the Winkler method, as described by Strickland \& Parsons (1972).

Benthic fluxes: Benthic fluxes of oxygen and nutrients were measured monthly using a chamber fitted over the benthos. The circular chamber was $1.76 \mathrm{~m}$ in diameter, $12 \mathrm{~cm}$ high and enclosed about 300 1. Triplicate initial, mid incubation and final chamber water samples were taken for determination of oxygen, dissolved inorganic carbon (infrared detector for DIC, precision equal to $2 \%$; O.I. Model 700 Total Organic Carbon Analyzer) and dissolved inorganic nutrients. Control bottles were incubated to correct for water column changes.

Zooplankton: Zooplankton abundance and species composition were estimated from 2 vertical replicate tows taken every $2 \mathrm{wk}$ using a $30 \mathrm{~cm}$ diameter no. 20 net. This sampling procedure removes less than $2 \%$ of the population from the well-mixed enclosures.

Denitrification: Sediment denitrification was measured once using diver-collected cores taken on August 26, 1988. A complete description of the denitrification method is given in Nowicki (1994). Briefly, direct measurements of sediment $\mathrm{N}_{2}$ gas production were made from cores sealed in gas-tight chambers and incubated in the dark at ambient temperatures and water column nutrient and oxygen concentrations. Observed rates of $\mathrm{N}_{2}$ gas production were corrected for pore-water degassing fluxes using a regression of observed porewater fluxes in anoxic control cores (Nowicki 1994).

Nitrogen fixation: The potential for nitrogenase activity was estimated using the acetylene reduction assay (see Capone 1993). For fixation by plankton in the water column ('water column' fixation), we used $40 \mathrm{ml}$ water samples and measured the rate of acetylene-dependent ethylene production over time. We used the $1 \mathrm{~h}$ sample as our time zero to correct for the ethylene contamination contained in the acetylene, this contamination was significant. Incubations were performed in an incubator at $\sim 250 \mu$ Ein $\mathrm{m}^{-2} \mathrm{~s}^{-1}$ within $\pm 2^{\circ} \mathrm{C}$ of ambient temperature. We also attempted to estimate the rate of $\mathrm{N}_{2}$ fixation by attached organisms. In normal operating mode the walls of the enclosures are brushed to prevent the accumulation of periphyton and fouling organisms. In this experiment a patch of wall $\left(1 \mathrm{~m}^{2}\right)$ was deliberately left uncleaned to examine the potential for $\mathrm{N}_{2}$ fixation. We sampled wall growth by vigorously scrubbing the material from a standard area $\left(100 \mathrm{~cm}^{2}\right)$ and collecting it quantitatively, analodusk-dawn to estimate the system's apparent daytime 
gously to the way periphyton is sampled from rocks. This material was diluted with water from the same enclosure, and acetylene reduction was assayed as above.

Our ability to estimate total nitrogen fixation for the enclosures was limited for several reasons. Our estimates were based entirely upon the acetylene reduction assay without confirmation with ${ }^{15} \mathrm{~N}$ (see Capone 1993). Secondly, we assayed at a single light level $\left(\sim 250 \mu\right.$ Ein $\left.\mathrm{m}^{-2} \mathrm{~s}^{-1}\right)$. The enclosures vary in light from more than $1500 \mu$ Ein $\mathrm{m}^{-2} \mathrm{~s}^{-1}$ at the surface to about $10 \mu$ Ein $\mathrm{m}^{-2} \mathrm{~s}^{-1}$ at the $5 \mathrm{~m}$ bottom depth. Autotrophic nitrogen fixation is usually a saturating function of light level and would probably be greater than we estimate at the surface and lower than we estimate at depth (Lewis \& Levine 1984). To bracket the actual rates of nitrogen fixation we make the following assumptions for 2 possible scenarios: (1) the fixation on the walls is autotrophic but the fixation on the sediments which receive less than $1 \%$ light and in the water column is heterotrophic; (2) the fixation on the walls and in the water column is autotrophic but the fixation on the sediments is heterotrophic. We assume that autotrophic fixation is light dependent and follows the light response given by Fig. 1 in Lewis \& Levine (1984). We assume heterotrophic fixation is independent of light. For the water column and walls we use our measurements of acetylene reduction. For the sediments we use the value of Seitzinger et al. (1980) for the sediments of Narragansett Bay in the enclosures not receiving nitrogen and 0 in the enclosures receiving nitrogen.

\section{RESULTS}

\section{System metabolism and phytoplankton biomass}

Productivity and phytoplankton biomass concentrations indicated nitrogen limitation (Fig. 1). Mean apparent system daytime production $\left(\mathrm{g} \mathrm{O}_{2} \mathrm{~m}^{-2} \mathrm{~d}^{-1}\right)$ increased from 1.8 in controls and 0.7 in phosphorus treatments to 5.5 in nitrogen treatments and 5.4 in nitrogen + phosphorus treatments over the first 2 mo of the experiment. Nighttime respiration showed similar patterns of increase in nitrogen treatments. Over the same period average chlorophyll concentration

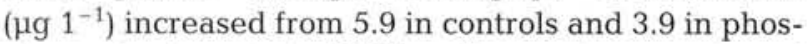
phorus treatments to 31.2 in nitrogen treatments and 25.5 in nitrogen + phosphorus treatments. In the 3 parameters approximately a 5 -fold increase occurred in the nitrogen-enriched systems, whereas phosphorus-enriched systems experienced somewhat lower metabolism and phytoplankton biomass than controls. Peak chlorophyll concentrations (as opposed to mean
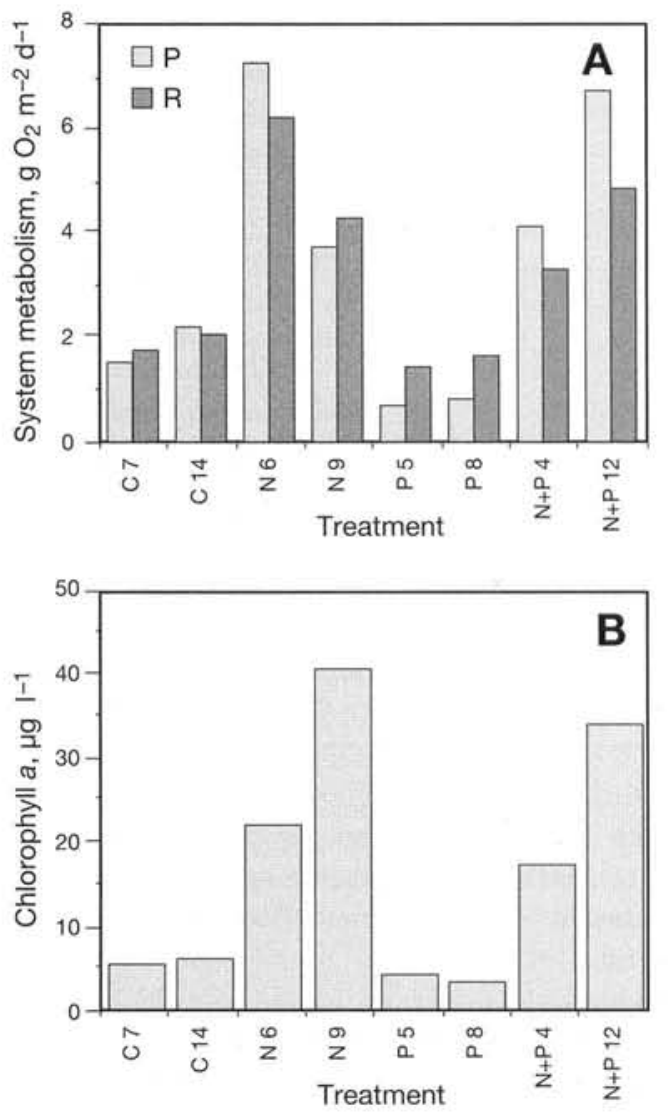

Fig. 1. Productivity responses to the various nutrient treatments. (A) Mean system daytime apparent production (P) and system nighttime respiration $(R)$ in the nutrient treatments from June 8 to August 10, 1988. (B) Mean phytoplankton biomass in the treatments over the same period. Letters refer to nutrient treatment and numbers to individual enclosures on the $X$-axis; thus $C 7$ and $C 14$ are control replicates in enclosures 7 and 14

values in Fig. 1) in the nitrogen treatments of 70 and $114 \mu \mathrm{g} \mathrm{l}^{-1}$ can be compared with peak concentrations in Lake 226 of 50 and $115 \mu \mathrm{g} \mathrm{l}^{-1}$ (Schindler 1974). These results lead to the conclusion that nitrogen was limiting but that phosphorus was not. Even in the nitrogen treatment which did not receive phosphorus, phosphorus was apparently not limiting since phytoplankton responded in a similar magnitude in both the nitrogen treatment and the nitrogen + phosphorus treatment (Fig. 1).

Phytoplankton in replicate treatments displayed variability (compare N6 and N9) which can not be attributed to nutrient treatment. Some of this variability may be explained by grazing. System production in replicates across treatments was correlated with zooplankton abundance $\left(\mathrm{R}^{2}=0.848\right.$, data missing for control in enclosure 14 and $\mathrm{N}+\mathrm{P}$ in enclosure 12), suggesting some degree of top-down control on phytoplankton. 
The addition of nitrogen caused the systems to switch from net heterotrophy to net autotrophy. Typically control systems and Narragansett Bay are heterotrophic during the summer period when diatom production is usually low and respiration of the system is high (Oviatt et al. 1986). Net ecosystem production (apparent daytime production minus nighttime respiration) is often negative, indicating more organic carbon is consumed than is produced. The control treatments and the phosphorus treatments both demonstrated net heterotrophy, with mean negative values of -0.08 and $-0.79 \mathrm{~g} \mathrm{O}_{2} \mathrm{~m}^{-2} \mathrm{~d}^{-1}$. By contrast, the mean of both nitrogen treatments showed net ecosystem production. In the nitrogen treatments, the value of $0.28 \mathrm{~g} \mathrm{O}_{2} \mathrm{~m}^{-2} \mathrm{~d}^{-1}$ was small and in the nitrogen + phosphorus treatments it was about $30 \%$ of system production with a mean value of $1.33 \mathrm{~g} \mathrm{O}_{2} \mathrm{~m}^{-2} \mathrm{~d}^{-1}$. The stimulation of respiratory processes apparently lagged behind productivity processes in these treatments.

\section{Nutrients}

Ammonia added to the water column of the treatment enclosures decreased rapidly during the initial 2 wk of the experiment and was less than $10 \mu \mathrm{M}$ after July 6 (Fig. 2). Phosphorus concentrations also decreased, but only in the nitrogen + phosphorus treatment did they decrease close to the Redfield ratio. Redfield (1958) reported atomic ratios of available nitrogen to phosphorus of 15:1 in seawater, depletion of nitrogen to phosphorus in the ratio of 15:1 during phytoplankton growth, and ratios of 16:1 for laboratory analysis of phytoplankton. In our study regression analysis indicated that ammonia was depleted relative to phosphorus in the ratio of $17: 1$ in the nitrogen + phosphorus treatments; this ratio was $146: 1$ in the nitrogen treatments $\left(R^{2}=0.967\right.$ and 0.516 respectively). Phosphorus concentration in the nitrogen treatment was always less than $1 \mu \mathrm{M}$ except for the last date and dropped to $0.01 \mu \mathrm{M}$ in one replicate and $0.05 \mu \mathrm{M}$ in the other replicate.

Except for added phosphorus, nutrients were very low in the phosphorus and control treatments. Phosphate added to the water column of the phosphorus treatment enclosure decreased slowly from about $10 \mu \mathrm{M}$ to about $5 \mu \mathrm{M}$ over the experimental period. By contrast, inorganic nitrogen in these replicates was less than $1 \mu \mathrm{M}$, with 2 isolated exceptions. In control treatments phosphate slowly rose from less than 1 to slightly above $1 \mu \mathrm{M}$ over the experiment. Inorganic nitrogen in control treatments was always less than $1 \mu \mathrm{M}$ and usually less than $0.5 \mu \mathrm{M}$.

Particulate nitrogen and phosphorus were measured in each enclosure (except the second replicate of $\mathrm{N}+\mathrm{P}$ )
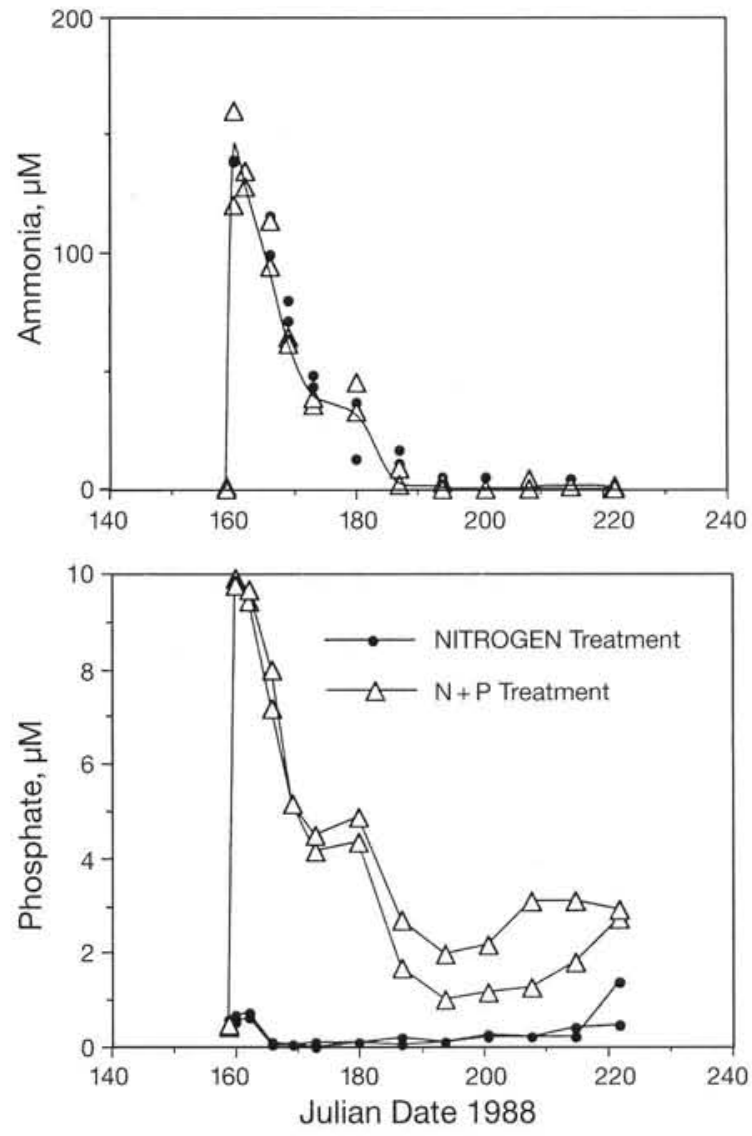

Fig. 2. Weekly nutrient concentrations of ammonia and phosphorus in the replicate nitrogen and nitrogen + phosphorus nutrient treatments during the first $3 \mathrm{mo}$ of the experiment. Legend for treatments is given for both graphs in the bottom graph

during the first $10 \mathrm{~d}$ of the experiment when the greatest productivities occurred (Table 2). Lowest N:P ratios occurred in control and phosphorus treatments and highest ratios occurred in the nitrogen treatments. The mean phosphorus treatment ratio of 50 falls within the nitrogen-limited range which may go as high as 110 in marine plankton (Valiela 1984).

Benthic nutrient flux indicated more nitrogen remineralization in nitrogen treatments than in control or phosphorus treatments (Table 3 ). Regeneration rates for phosphorus had no trend in magnitude with treatment and were all quite similar. The mean atomic ratios of $\mathrm{N}: \mathrm{P}$ in benthic fluxes were about 20 in both nitrogen treatments, slightly less than a Redfield value in the phosphorus treatment and about half of a Redfield value in the control treatments.

Nitrogenase activity in the water column was lowest in both nitrogen and nitrogen + phosphorus treatments, with erratic small bursts of activity, especially later in the experiment after the ammonium had 
Table 2. Mean particulate N:P ratios by atom (Days 162 to $173, \mathrm{n}=4)$, and comparison of ratios in input water and benthic fluxes

\begin{tabular}{|c|c|c|c|}
\hline \multicolumn{2}{|c|}{ Treatment } & $N: P$ & Range \\
\hline \multicolumn{2}{|c|}{$\mathrm{C}$} & 10 & $9-16$ \\
\hline \multicolumn{2}{|c|}{$\mathrm{C}$} & 9 & $3-19$ \\
\hline \multicolumn{2}{|c|}{$\mathrm{N}$} & 60 & $32-102$ \\
\hline \multicolumn{2}{|c|}{$\mathrm{N}$} & 40 & $16-75$ \\
\hline \multicolumn{2}{|c|}{ P } & 12 & $5-30$ \\
\hline \multicolumn{2}{|c|}{$\mathrm{P}$} & 10 & $3-19$ \\
\hline \multicolumn{2}{|c|}{$\mathrm{N}+\mathrm{P}$} & 19 & $5-30$ \\
\hline \multicolumn{4}{|c|}{ Comparison of ratios } \\
\hline Treatment & $\begin{array}{l}\text { Initial water } \\
\text { column N:P }\end{array}$ & $\begin{array}{c}\text { Benthic flux } \\
\text { N:P }\end{array}$ & $\begin{array}{c}\text { Particulates } \\
\text { N:P }\end{array}$ \\
\hline $\mathrm{C}$ & 1.3 & 8 & 10 \\
\hline $\mathrm{N}$ & 260 & 20 & 50 \\
\hline $\mathrm{P}$ & 0.03 & 14 & 11 \\
\hline $\mathrm{N}+\mathrm{P}$ & 14 & 21 & 19 \\
\hline
\end{tabular}

depleted (Fig. 3). In both the control and phosphorus treatments nitrogenase activity occurred at moderate rates but was highly variable over time and among enclosures, occurring in occasional blooms. Nitrogenase activity from the walls followed a similar erratic pattern but was low to nonexistent in both the nitrogen and nitrogen + phosphorus treatments throughout the entire $9 \mathrm{wk}$ experiment (Fig. 3). Scrapings from the walls were rich in heterocystic cyanobacteria such as Calothrix and Rivularia in the control and phosphorus enclosures. Intriguingly, despite the consistently detectable nitrogenase activity in the water columns of the control and phosphorus enclosures, we did not find heterocystic cyanobacteria. The agent of nitrogenase

Table 3. Mean benthic nutrient flux $\left(\mu \mathrm{M} \mathrm{m} \mathrm{m}^{-2} \mathrm{~h}^{-1}\right)$ from monthly measurements, compared to denitrification rates (August measurement) and average nitrogen fixation rates from biweekly measurements. nm: no measurement

\begin{tabular}{|lrrrr|}
\hline \multirow{2}{*}{ Benthic flux } & \multicolumn{4}{c|}{ Treatment } \\
& $\mathrm{C}$ & $\mathrm{N}$ & $\mathrm{P}$ & $\mathrm{N}+\mathrm{P}$ \\
\hline $\mathrm{CO}_{2}$ & 1689 & 2257 & 1403 & 3136 \\
$\mathrm{NH}_{4}$ & 92 & 204 & 121 & 301 \\
$\mathrm{NO}_{\mathrm{x}}$ & 21 & 30 & 17 & $\mathrm{~nm}$ \\
$\mathrm{PO}_{4}$ & 15 & 11 & 11 & 16 \\
$\mathrm{~N}: \mathrm{P}$ & 8 & 20 & 14 & 21 \\
Denitrification- $\mathrm{N}$ & 81 & 165 & 66 & 84 \\
Fixation- $\mathrm{N}^{\mathrm{a}}$ & $10-26$ & $0.8-3$ & $16-30$ & $0.8-2$ \\
& & & & \\
${ }^{a} \mu \mathrm{M} \mathrm{m}^{-2} \mathrm{~h}^{-1}$, where $\mathrm{h}$ is 'average' hour of the $24 \mathrm{~h}$ day \\
\hline
\end{tabular}

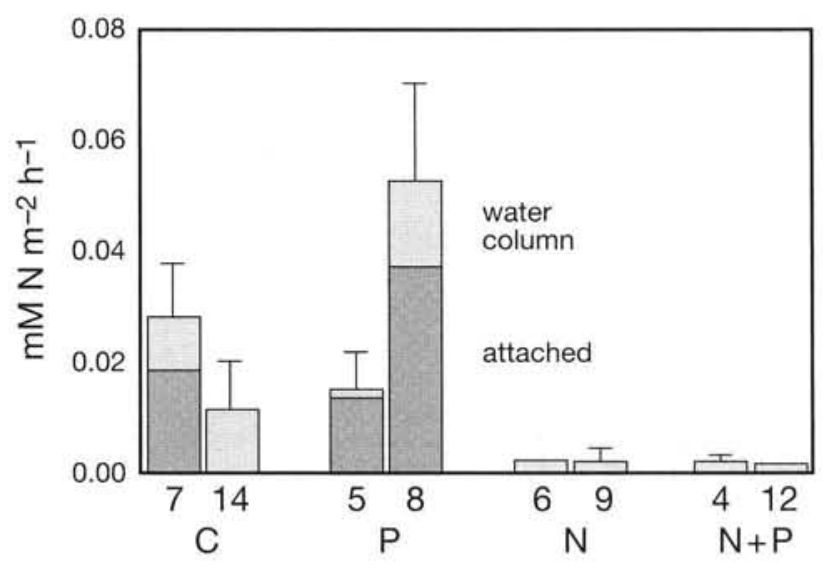

Fig. 3. Hourly rates of nitrogen fixation, assayed at a single light level, based on the 'autotrophic' assumption (see text). C: control treatment; numbers on $\mathrm{X}$-axis are enclosure numbers

activity in the water columns may have been heterotrophic bacteria (Paerl et al. 1987), or may have been isolated heterocysts sloughed from the enclosure walls.

Using the assumptions described in the 'Methods', nitrogen fixation in the nitrogen and nitrogen + phosphorus enclosures would range from about 0.02 to about $0.1 \mathrm{mM} \mathrm{N} \mathrm{m}^{-2} \mathrm{~d}^{-1}$ (depending on scenario) and in enclosures not receiving nitrogen (control and phosphorus enclosures) the rate would be from 10- to $36-$ fold greater (Table 3). The highest rates of fixation occurred in the phosphorus enclosures $\left(0.4 \mathrm{mM} \mathrm{m}^{-2}\right.$ $\mathrm{d}^{-1}$ for scenario 2 and $0.7 \mathrm{mM} \mathrm{m}^{-2} \mathrm{~d}^{-1}$ for scenario 1) but the rates in the control enclosures were nearly as high ( 0.2 and $0.6 \mathrm{mM} \mathrm{m}^{-2} \mathrm{~d}^{-1}$, respectively).

Denitrification rates were lower than benthic dissolved inorganic nitrogen regeneration rates and from equal to 2 orders of magnitude higher than nitrogen fixation rates (Table 3). Values of 66 to $84 \mu \mathrm{M} \mathrm{N} \mathrm{m}^{-2}$ $\mathrm{h}^{-1}$ were measured in all treatments except the nitrogen treatment, which had a value of about 165 as compared with a benthic $\mathrm{N}$ flux of about 200. Benthic denitrification rates in the nitrogen + phosphorus treatment were only about one third of the benthic remineralization rates for nitrogen in that treatment. Benthic denitrification rates of about $100 \mu \mathrm{M} \mathrm{N} \mathrm{m}^{-2} \mathrm{~h}^{-1}$ have been reported for Narragansett Bay (Seitzinger et al. 1984).

\section{DISCUSSION}

Bottle incubations in coastal marine systems in the northeast United States suggest nitrogen is the primary nutrient limiting to phytoplankton production. Our ecosystem level experiment confirms this result. 
Systems receiving a nitrogen addition had a higher primary productivity and respiration, a higher biomass and a higher mean net ecosystem production. The addition of nitrogen switched the systems from net heterotrophy to net autotrophy with the exception of N9. This higher metabolism and biomass occurred with and without a phosphorus addition (Fig. 1). Added nitrogen was rapidly depleted from the water column but phosphorus was not, suggesting that even in the nitrogen and nitrogen + phosphorus treatments, nitrogen was still limiting. Further, the addition of phosphorus alone did not stimulate either metabolism or biomass, and metabolism and biomass were about equal in the nitrogen and nitrogen + phosphorus treatment. In these whole-system marine experiments, then, nitrogen was clearly the nutrient most limiting to primary production.

The question arises as to where the phosphorus came from to support the bloom in the nitrogen treatment? Phosphorus could only have come from 2 sources, the water column reservoir and benthic fluxes (Fig. 2, Tables $2 \& 3$ ). If the decrease in added nitrogen and standing stock of phosphorus in the water column is assumed to occur in $30 \mathrm{~d}$ (Fig. 2) and if this daily decrease is subsidized by benthic flux (Table 3 ) then the predicted N:P uptake ratio becomes $62: 1$. This predicted ratio compares favorably with the observed particulate ratio of $40: 1$ to $60: 1$ (Table 2). This comparison is helpful because the particulate ratio might include some fraction of refractory detritus moving the ratio far from the Redfield ratio of 15 or 16. Apparently organic matter need not conform to the Redfield ratio, although the nitrogen + phosphorus treatment indicates that when the nutrients are available organic matter forms this ratio. Data compiled from many sources indicated that the $\mathrm{N}$ :P ratio of marine phytoplankton can be as high as 110 or greater (Valiela 1984, Hecky \& Kilham 1988).

In a series of classic papers, D. W. Schindler (e.g. Schindler 1976, 1977) set out to explain the factors that lead to phosphorus limitation in freshwaters, and these include both external factors such as nutrient loading ratios, and internal factors, including biological and geochemical reactions. Schindler (1976) argued that, at least for the pre-Cambrian Shield Lakes he studied, 2 internal factors were critical. First, phosphorus was irreversibly sorbed to sediments and not released under either oxic or anoxic conditions. Second, biological nitrogen fixation (by cyanobacteria) had the potential to make up a nitrogen deficit and return the system to phosphorus limitation. Either or both factors can be important in different systems at different times. For example, in Lake 261 which was fertilized with phosphorus alone, planktonic nitrogen fixation was not detected but phosphorus was nevertheless 90 to $95 \%$ immobilized in sediments (Schindler 1976). In Lake 227 which was fertilized with nitrogen and phosphorus, planktonic fixation was stimulated and phosphorus was sorbed to sediments (Schindler 1976).

Differences in both nitrogen and phosphorus cycling between fresh and marine systems were critical to the maintenance of nitrogen limitation in this marine whole-system experiment. In our marine experiment, phosphorus was not irreversibly bound to sediments, consistent with Caraco et al. (1990), and nitrogen fixation, although abnormally and perhaps erroneously high for a marine environment, was still insufficient to make up the nitrogen deficit that occurred by nitrogen uptake and denitrification.

Smith (1991) has criticized bottle incubation and microcosm studies on the basis that they may omit controlling processes. In this whole system experiment an effort was made to assess important processes like the role of nitrogen fixation and a more limited effort was made to assess the role of denitrification. The results provide evidence that both processes occurred at rates comparable to literature values (Table 3). Nitrogen fixation rates (both attached and in the water column) in the nitrogen treatments were comparable to values measured in oligotrophic lakes and in marine waters (Howarth et al. 1988). In the control and phosphorus enclosures, however, measured nitrogen fixation in the water column was unexpectedly high and difficult to explain, especially in the absence of known cyanobacterial fixers in the water column. If accurate, the nitrogen fixation rates in control and phosphorus treatments would be among the highest reported for a temperate estuary near full salinity and warrant some explanation. The enclosures were run in batch mode, without replacement of water from the bay. With this design, rates of nitrogen fixation may have been maximized and advective losses minimized. The concentrations of both ammonium and nitrate, for example, were much lower in the control enclosure than in the bay, which continues to receive nitrogen inputs from the watershed. Ammonium concentrations in the control enclosures averaged $0.44 \mu \mathrm{M}, 7$-fold lower than in the bay; nitrate concentrations averaged $0.2 \mu \mathrm{M}$ in the enclosures, 5-fold lower than in the bay. The lower combined nitrogen concentrations in the enclosures may have allowed for increased nitrogen fixation. Whatever nitrogen fixation occurred in the phosphorus treatment did not compensate for the nitrogen deficit sufficiently to allow productivity to increase to levels comparable to treatments with added nitrogen. Denitrification rates were generally higher than rates of nitrogen fixation although less than benthic flux rates (Table 3) and somewhat less than rates of denitrification measured in Narragansett Bay (Seitzinger et al. 1984). However, only 1 set of these August measure- 
ments were made and extrapolated for the experimental period. The method was direct and utilized a regression analysis of anoxic control values to correct for passive gas flux (Nowicki 1994). These denitrification losses of nitrogen may be a significant sink for dissolved inorganic nitrogen, particularly in the nitrogen treatments (see Tables $3 \& 4$ ).

Since the measured nitrogen fixation rates have large uncertainties and because we only made 1 set of denitrification measurements we have also calculated these rates with the following equations:

\section{(A) Denitrification:}

Benthic $\mathrm{CO}_{2}$ flux, molar units $=$ (Potential
benthic DIN flux $) \times \mathrm{C}: \mathrm{N}_{\text {seston }}$
Potential benthic DIN flux - Measured DIN
flux = Denitrification

(B) Nitrogen fixation:

(Standing stock decrease of $\mathrm{PO}_{4}$ in water + Benthic $\mathrm{PO}_{4}$ flux $) \times \mathrm{N}: \mathrm{P}_{\text {seston }}=\mathrm{N}$ demand

$\mathrm{N}$ demand - Standing stock decrease of DIN + Benthic DIN flux = N fixation

The agreement between measured and calculated denitrification and measured and calculated nitrogen fixation demonstrates internal consistency in our measurements (Table 4). The agreement provides some confidence in both the pattern and magnitudes of denitrification and nitrogen fixation.

The mesocosm approach did describe the summed functions of the system (Smith 1991). Typical results of bottle assays are (1) nitrogen addition alone results in greater productivity than controls and (2) nitrogen + phosphorus additions result in still greater productivity, suggesting that the addition of nitrogen alone eventually results in a secondary phosphorus limitation. In this mesocosm experiment, which did not isolate the water

Table 4. Calculated mean measurements of denitrification and nitrogen fixation rates, compar ${ }^{-1}$ to mean measured rates; all values in $\mu \mathrm{M} \mathrm{...}{ }^{-2} \mathrm{~h}^{-1}$

\begin{tabular}{|lrc|}
\hline Treatment & Calculated & Measured \\
\hline Denitrification & & \\
C & 88 & 81 \\
N & 93 & 165 \\
P & 62 & 66 \\
N+P & 202 & 84 \\
Nitrogen fixation & & \\
C & 24 & $10-26$ \\
N & 4 & $0.8-3$ \\
P & 65 & $16-30$ \\
N+P & 0 & $0.8-2$ \\
\hline
\end{tabular}

column from benthic nutrient recycling, no such secondary phosphorus limitation could be inferred in the nitrogen-alone treatments. Rather, a benthic input of phosphorus and formation of organic matter with a high $\mathrm{N}: \mathrm{P}$ ratio allowed added nitrogen to be utilized to the same extent as when additional phosphorus was added.

This is an experiment that unequivocally indicates nitrogen limitation at the system level in the coastal marine environment of the U.S. northeast. The complexity of the controlling processes obscures the exact detailed mechanisms of that limitation. Nevertheless, in striking contrast to similar fertilization experiments in Canadian lakes a phosphate supply, sufficient to utilize available nitrogen, was maintained either by direct addition or by recycling. In treatments where phosphorus was added, this phosphorus was taken up by phytoplankton rather than being depleted by competing geochemical processes as in lakes. Despite a surfeit of phosphorus in the phosphorus-alone treatment, nitrogen fixation was insufficient to alleviate nitrogen limitation and allow increased productivity. In systems where only nitrogen was added, both recycling of phosphorus from the benthos and formation of organic matter depleted in phosphorus allowed utilization of added nitrogen and enhanced productivity.

Acknowledgements. This research was funded primarily by the U.S. Environmental Protection Agency Cooperative Agreement CR812487-02,-03 and in part by the Andrew W. Mellon Foundation. Robert Howarth provided critical comments which improved the paper.

\section{LITERATURE CITED}

Brewer, P. G., Riley, J. P. (1966). The automatic determination of silicate-silicon in natural waters with special reference to seawater. Analyt. Chim. Acta 35: 514-519

Capone, D. G. (1993). Determination of nitrogenase activity in aquatic samples using acetylene reduction procedure. In: Kemp, M., Sherr, P. F., Sherr, E. B., Cole, J. (eds.) Handbook of methods in aquatic microbial ecology, Chap. 23. Lewis Publishers, Boca Raton, FL, p. 621-631

Caraco, N., Cole, J., Likens, G. (1990). A comparison of phosphorus immobilization in sediments of freshwater and coastal marine systems. Biogeochemistry 9: 277-290

Caraco, N., Tamse, A., Boutros, O., Valiela, I. (1987). Nutrient limitation of phytoplankton growth in brackish coastal ponds. Can. J. Fish. Aquat. Sci. 44: 473-476

D'Elia, C. F., Sanders, J. G., Boynton, W. R. (1986). Nutrient enrichment studies in a coastal plain estuary: phytoplankton growth in large-scale, continuous culture, Can. J. Fish. Aquat. Sci. 43: 397-406

Hager, S. W., Atlas, E. L., Fordon, L. I., Mantyla, A. W., Park, P. K. (1972). A comparison at sea of manual and autoanalyzer analyses of phosphate, nitrate and silicate. Limnol. Oceanogr. 17: 931-937

Hecky, R. E., Kilham, P. (1988). Nutrient limitation of phytoplankton in freshwater and marine environments: a review of recent evidence on the effects of enrichment. Limnol. Oceanogr. 33(4, part 2): 796-822 
Howarth, R. W. (1988). Nutrient limitation of net primary production in marine ecosystems. A. Rev. Ecol. Syst. 19: 89-110

Howarth, R. W., Marino, R., Lane, J., Cole, J. J. (1988), Nitrogen fixation in freshwater, estuarine and marine ecosystems. 1. Rates and importance. Limnol. Oceanogr. 33(4, part 2): $669-687$

Lambert, C. E., Oviatt, C. A. (eds.) (1986). Manual of biological and geochemical techniques in coastal areas. MERL Series Report No. 1, 2nd edn. Marine Ecosystems Research Laboratory, University of Rhode Island, Narragansett

Lewis, W. M. Jr, Levine, S. N. (1984). The light response of nitrogen fixation in Lake Valencia, Venezuela. Limnol. Oceanogr. 29: 894-900

Lorenzen, C. J. (1966). A method for continuous measurement of in vivo chlorophyll concentration. Deep Sea Res. 13: 223-227

MacDonald, R. W., McLaughlin, F. A., Wong, C. S. (1986). The storage of reactive silicate samples by freezing. Limnol. Oceanogr. 31: 1139-1141

Nowicki, B. L. (1994). The effect of temperature, oxygen, salinity, and nutrient enrichment on estuarine denitrification rates measured with a modified nitrogen gas flux technique. Estuar. coast. Shelf Sci. 38: 137-156

Oviatt, C. A., Keller, A. A., Sampou, P. A., Beatty, L. L. (1986). Patterns of productivity during eutrophication: a mesocosm experiment. Mar. Ecol. Prog. Ser. 28: 69-80

Paerl, H. W., Crocker, K. M., Prufert, L. E. (1987). Limitation of $\mathrm{N}_{2}$ fixation in coastal marine waters: relative importance of molybdenum, iron, phosphorus and organic matter availability. Limnol. Oceanogr. 32: 525-536

Redfield, A. C. (1958). The biological control of chemical factors in the environment. Am. Scient. 46: 206-226

Ryther, J. H., Dunstan, W. M. (1971). Nitrogen, phosphorus and eutrophication in the coastal marine environment. Science 171: 1008-1013

Samuelsson, G., Oquist, G. (1977). A method for studying photosynthetic capacity of unicellular algae based on in vivo chlorophyll fluorescence. Physiol. Plant. 40: 315-319

Schindler, D. W. (1974). Eutrophication and recovery in experimental lakes. Science 184: 897-899

This article was submitted to the editor
Schindler, D. W. (1977). Natural mechanisms compensate for deficiencies of nitrogen and carbon in eutrophied lakes. Science 195: 260-262

Schindler, D. W. (1976). Biogeochemical evolution of phosphorus limitation in nutrient enriched lakes of precambrian shield. In: Nriagu, J. O. (ed.) Environmental geochemistry, Chap. 41. Ann Arbor Science, Ann Arbor, p. 647-664

Seitzinger, S. P., Nixon, S. W., Pilson, M. E. Q. (1984). Denitrification in freshwater and coastal marine ecosystems: ecological and geochemical significance. Limnol. Oceanogr. 33: 702-724

Seitzinger, S. P., Nixon, S., Pilson, M. E. Q., Burke, S. (1980). Denitrification and $\mathrm{N}_{2} \mathrm{O}$ production in nearshore marine sediments. Geochim. cosmochim. Acta 44: 1853-1860

Smith, S. V. (1984). Phosphorus versus nitrogen limitation in the marine environment. Limnol. Oceanogr. 29: $1149-1160$

Smith, S. V. (1991). Stoichiometry of C:N:P fluxes in shallow water marine ecosystems. In: Cole, J., Lovett, G., Findlay, S. (eds.) Comparative analyses of ecosystem patterns, mechanisms, and theories. Springer-Verlag, New York, p. $259-286$

Solorzano, L. (1969). Determination of ammonia in natural waters by the phenolhypochlorite method. Limnol. Oceanogr. 14: 799-801

Strickland, J. D. H., Parsons, T. R. (1972). A practical handbook of seawater analysis, 2nd edn. Bull. Fish. Res. Bd Can. 167: 1-310

Valderrama, J. C. (1981). The simultaneous analysis of total nitrogen and total phosphorus in natural waters. Mar. Chem. 10: 109-122

Valiela, I. (1984). Marine ecological processes. SpringerVerlag, New York, p. 56, 59

Vitousek, P. M., Howarth, R. W. (1991). Nitrogen limitation on land and in the sea: How can it occur? Biogeochemistry 13: $87-115$

Yentsch, C. S., Menzel, D. W. (1963). A method for the determination of phytoplankton chlorophyll and phaeophytin by fluorescence. Deep Sea Res. 10: 221-231

Wood, E. D., Armstrong, F. A. J., Richards, F. A. (1967). Denitrification of nitrate in seawater by cadmium-copper reduction to nitrite. J. mar. biol. Ass. U.K. 47: 23-31

Manuscript first received: June 27, 1994

Revised version accepted: August 19, 1994 